\title{
INFLUENCE OF CULTURE MEDIUM ON THE PRODUCTION OF EIF ANTIGEN FROM LEISHMANIA CHAGASI IN RECOMBINANT ESCHERICHIA COLI
}

\author{
Michelle Rossana Ferreira Vaz ${ }^{1 *}$, Ricardo Luiz Soares de França ${ }^{1}$, Sirtys Santos Lessa de Andrade ${ }^{1}$, Francisco Canindé de \\ Sousa Junior ${ }^{1}$, Everaldo Silvino dos Santos ${ }^{1}$, Daniella Regina Arantes Martins ${ }^{2}$, Gorete Ribeiro de Macedo ${ }^{1}$ \\ ${ }^{1}$ Laboratório de Engenharia Bioquímica, Departamento de Engenharia Química, Universidade Federal do Rio Grande do Norte, \\ Natal, RN, Brasil; ${ }^{2}$ Laboratório de Imunogenética, Departamento de Biologia Celular e Genética, Universidade Federal do Rio \\ Grande do Norte, Natal, RN, Brasil.
}

Submitted: November 08, 2010; Returned to authors for corrections: February 18, 2011; Approved: May 30, 2011.

\begin{abstract}
With the advent of recombinant DNA technology, recombinant protein expression has become an important tool in the study of the structure, function and identification of new proteins, especially those with therapeutic functions. Escherichia coli has been the predominant prokaryote used in genetic engineering studies due to the abundance of information about its metabolism. Despite significant advances in molecular biology and immunology of infections, there are as yet no prophylactic drugs capable of preventing visceral leishmaniasis. It is therefore important to identify specific antigens in order to develop vaccines and diagnostic kits against this disease. The objective of this study was to evaluate the influence of culture medium on the production of eIF antigen from Leishmania chagasi in recombinant Escherichia coli. An induction procedure using IPTG was carried out in a series of trials, to observe the influence of culture medium (2xTY, TB) under expression of the recombinant eIF protein. Results showed that recombinant protein expression was associated to growth and that the highest eIF antigen expression was obtained in the 2xTY medium.
\end{abstract}

Key words: Cultivation, Recombinant protein; Visceral leishmaniasis, Escherichia coli

\section{INTRODUCTION}

Escherichia coli is the most commonly used host strain for the expression of heterologous proteins and biocatalysts (12, 18). These recombinant proteins are usually synthesized intracellularly in either the cytoplasm or the periplasmic space (2), and overall productivity is a function of both cell density and specific yield. Proteins such as interferons, interleukin and growth hormones are some of the recombinant proteins successfully expressed in E. coli (4). However, E. coli has a number of limitations in its expression system, including inability to carry out post-translational changes, common in eukaryotic cells, lack of secretion system for efficient release of the recombinant protein into the culture medium (1). Protein

\footnotetext{
*Corresponding Author. Mailing address: Departamento de Engenharia Química, Núcleo Tecnológico, Universidade Federal do Rio Grande do Norte, Av. Sen. Salgado Filho, 3000 - Campus Universitário, 59072-970, Natal, RN, Brazil.; Fax: +55 84 3215-3756.; E-mail: rossana@eq.ufrn.br
} 
expression in cytoplasm often leads to inadequate protein structure and agglutination in insoluble inclusion bodies (16).

With the advent of recombinant DNA technology, recombinant protein expression has become an important tool in the study of the structure, function and identification of new proteins, especially those with therapeutic functions, allowing for the manufacture of drugs capable of controlling particular diseases $(3,14)$.

Leishmaniases are illnesses caused by protozoa of the genus Leishmania, which, depending on the species, may produce cutaneous, mucocutaneous, diffuse or visceral manifestations (13). American visceral leishmaniasis or kalaazar is the most severe form of this disease. Untreated visceral leishmaniasis results in death within two years of initial infection (5). Despite significant advances in molecular biology and infection immunology, there are as yet no prophylactic drugs capable of preventing this disease, justifying the need to identify specific antigens, in order to develop vaccines and diagnostic kits against visceral leishmaniasis (11).

Thus, the objective of this study was to evaluate the influence of culture medium on the production of eIF antigen from Leishmania chagasi in recombinant Escherichia coli during batch fermentation using two different media (2xTY and TB).

\section{MATERIAL AND METHODS}

\section{Escherichia coli strain}

The Escherichia coli M15 strain with the eIF antigen used in this study was kindly donated by Dr. Mary Wilson (University of Iowa, U.S.A). The gene encoding the eIF antigen was expressed as a fusion protein containing histidine tag at the N-terminal end of the peptide using pQE-40 cloned in E. coli M15 cells (Qiagen, U.S.A). The strain was maintained on Luria-Bertani (LB) medium in the presence of ampicillin and kanamycin, as described elsewhere (16).

\section{Culture medium}

Culture media were prepared with distilled water and sterilized at $120^{\circ} \mathrm{C}$ for 20 minutes, while antibiotics and IPTG solutions were sterilized by filtration through a $0.22 \mu \mathrm{m}$ membrane in aseptic conditions. After sterilization, solutions were stored at $-20^{\circ} \mathrm{C}$. 2 XTY medium $(16 \mathrm{~g} / \mathrm{L}$ tryptone, $10 \mathrm{~g} / \mathrm{L}$ yeast extract, $5 \mathrm{~g} / \mathrm{L} \mathrm{NaCl}, \mathrm{pH}$ 7.0) and Terrif broth (TB) complex cultivation medium (12 g/L tryptone, $24 \mathrm{~g} / \mathrm{L}$ yeast extract, $0.004 \mathrm{~mL} / \mathrm{L}$ glycerol, $12.54 \mathrm{~g} / \mathrm{L} \quad \mathrm{KH}_{2} \mathrm{PO}_{4}, 15 \mathrm{~g} / \mathrm{L}$ $\mathrm{K}_{2} \mathrm{HPO}_{4}, \mathrm{pH}$ 7.0) were prepared according to Jordan et al. (7). For all experiments, media were used for batch cultivations in shake flasks supplemented with $0.1 \mathrm{~g} / \mathrm{L}$ ampicillin (Invitrogen, Brazil) and $0.025 \mathrm{~g} / \mathrm{L}$ kanamycin (Invitrogen, Brazil).

\section{Inoculum preparation}

The stock of E. coli strain containing the eIF antigen was stored at $-80^{\circ} \mathrm{C}$ in $50 \%$ glycerol. Two hundred microliters of stock was transferred to $50 \mathrm{~mL}$ of previously sterilized $2 \mathrm{xTY}$ and TB medium supplemented with $0.1 \mathrm{~g} / \mathrm{L}$ ampicillin and $0.025 \mathrm{~g} / \mathrm{L}$ kanamycin, using $250 \mathrm{~mL}$ Erlenmeyer flasks. Samples were kept in the shaker $\left(37^{\circ} \mathrm{C}, 200 \mathrm{rpm}\right)$ overnight. This suspension consisted of the initial inoculum batch cultivation carried out in a shaker flask.

\section{Cultivation conditions}

The cultivation inoculum $(10 \% \mathrm{v} / \mathrm{v})$ was transferred to 250 $\mathrm{mL}$ Erlenmeyer flasks and kept under agitation at $200 \mathrm{rpm}$ for 8 hours at $37^{\circ} \mathrm{C}$. To understand the IPTG induction effect on growth and eIF antigen expression, cultures were induced by the addition of a final concentration of $1 \mathrm{mM}$ IPTG when optical density $\left(\mathrm{OD}_{590 \mathrm{~nm}}\right)$ reached 0.5 (early log phase) (20). Samples were taken hourly from the shaker in which cultivated cells were harvested by centrifugation (Eppendorf centrifuge 5415D) at $16,100 \mathrm{G}$ for $30 \mathrm{~min}$. The precipitate was used to determine dry weight at $80^{\circ} \mathrm{C}$ until constant weight was achieved. The supernatant was used to determine protein concentration by the Lowry method (10). All assays were performed in duplicate.

\section{Recombinant protein purification}

The encoding nucleotide sequence of the protein of 
interest was inserted into the pQE-40 vector (Qiagen, U.S.A). The recombinant protein obtained is tagged to a histidine tail with high affinity for nickel ions. Therefore, batch mode purification by immobilized metal affinity chromatography (IMAC) used Nickel Sepharose 6 Fast Flow resin (Ge Helthcare, Brazil).

The purification process was as follows: $5 \mathrm{~mL}$ of the fermentation broth was centrifuged at $16,100 \mathrm{G}$ for 30 minutes. The supernatant and cells were separated and stored at $-20^{\circ} \mathrm{C}$ for further purification. For extracellular protein purification, samples were used directly, according to the following process. Intracellular proteins were first lysed with urea lysis buffer to release inclusion bodies $(10 \mathrm{mM}$ imidazole, $8 \mathrm{M}$ urea, $50 \mathrm{mM}$ $\mathrm{NaH}_{2} \mathrm{PO}_{4}, 0.5 \mathrm{M} \mathrm{NaCl}, \mathrm{pH}$ 8.0). During the lysis process, cells were put into an ice bath for 15 minutes, resuspended in lysis buffer and homogenized for 15-60 minutes. Cellular lysate was centrifuged at $16,100 \mathrm{G}$ for 30 minutes at ambient temperature. The supernatant was used for purification processing. In this case, after washing, $1 \mathrm{~mL}$ of elution buffer $(500 \mathrm{mM}$ imidazole, $50 \mathrm{mM} \mathrm{NaH} \mathrm{PO}_{4} 0.5 \mathrm{M} \mathrm{NaCl}, \mathrm{pH}$ 7.4) was added and homogenized for 5 minutes. The resin was settled by means of centrifugation at $16,100 \mathrm{G}$ for 5 minutes. The supernatant was removed and the process repeated four times to achieve complete desorption. The eluted product was used for quantitative (Lowry method) and qualitative (electrophoresis) analysis of the recombinant protein.

\section{Protein determination and electrophoresis}

Eluted fractions were collected and protein concentration was determined according to the Lowry method, using bovine serum albumin (BSA) as standard (8). Protein expression, assayed by electrophoresis in denaturing $15 \%$ polyacrylamide gel, was performed as described by Laemmli (9). A low molecular weight SDS calibration kit containing proteins (14.4 - $97.0 \mathrm{kDa}$ ) was used to provide standard molecular weight markers. Proteins were visualized by silver staining (17).

\section{RESULTS AND DISCUSSION}

Experiments were carried out using IPTG as inducer in order to observe the influence of medium composition on the expression of the Leishmania chagasi eIF antigen. Figure 1 shows intracellular eIF protein, extracellular and total protein concentration (intra and extracellular) when 2xTY medium was used. It can be observed that eIF protein production was associated to growth behavior, with a maximum specific protein yield $\left(\mathrm{Y}_{\mathrm{p} / \mathrm{x}}\right)$ of $0.37 \mathrm{~g} / \mathrm{g}$ occurring after $6 \mathrm{~h}$ of cultivation. This corresponded to the maximum eIF protein fraction that cells could accumulate before initiating lysis. It was observed that the highest expression occurred after 6 hours of cultivation, with a protein content of $0.11 \mathrm{~g} / \mathrm{L}$, while maximum intracellular protein concentration was $0.37 \mathrm{~g} / \mathrm{L}$. In terms of location (intracellular or extracellular), it can be observed that cells retain most of their protein during the exponential growth phase. After this phase, a decrease in both intracellular and extracellular protein occurred. This may be due to cellular lysis resulting from protein saturation in the cell.

Figure 2 shows that maximum eIF concentration in TB medium was $0.35 \mathrm{~g} / \mathrm{L}$ of total protein. The eIF protein expression demonstrated associated growth behavior, with maximum specific protein yield $\left(\mathrm{Y}_{\mathrm{p} / \mathrm{x}}\right)$ of $0.095 \mathrm{~g} / \mathrm{g}$ after 16 hours of cultivation. It can be observed that the highest intracellular expression occurred at 8 hours of cultivation. Additionally, cells retain most of their protein with an intracellular concentration of $0.15 \mathrm{~g} / \mathrm{L}$.

The influence of specific growth rate on eIF antigen expression was investigated. Figures 3 and 4 show the specific growth rate and protein concentration obtained during production of the eIF antigen in $2 \times T Y$ and TB medium, respectively. It can be observed that eIF recombinant protein production is associated with reduction in specific growth rate of the culture during the post- induction period. The specific 
growth rate results in both media are quite similar to those obtained by Panda et al. (15). Addition of amino acids in the presence of high tryptone concentration, as occurred in 2xTY medium, may reduce product degradation by proteases induced during amino acid limitation. Likewise, addition of casamino acids or peptone may enhance recombinant protein stability or synthesis, resulting in high protein levels compared to TB medium rich in yeast extract, which supplies bacteria with nitrogen and organic and inorganic nutrients, favoring only cell growth (6).

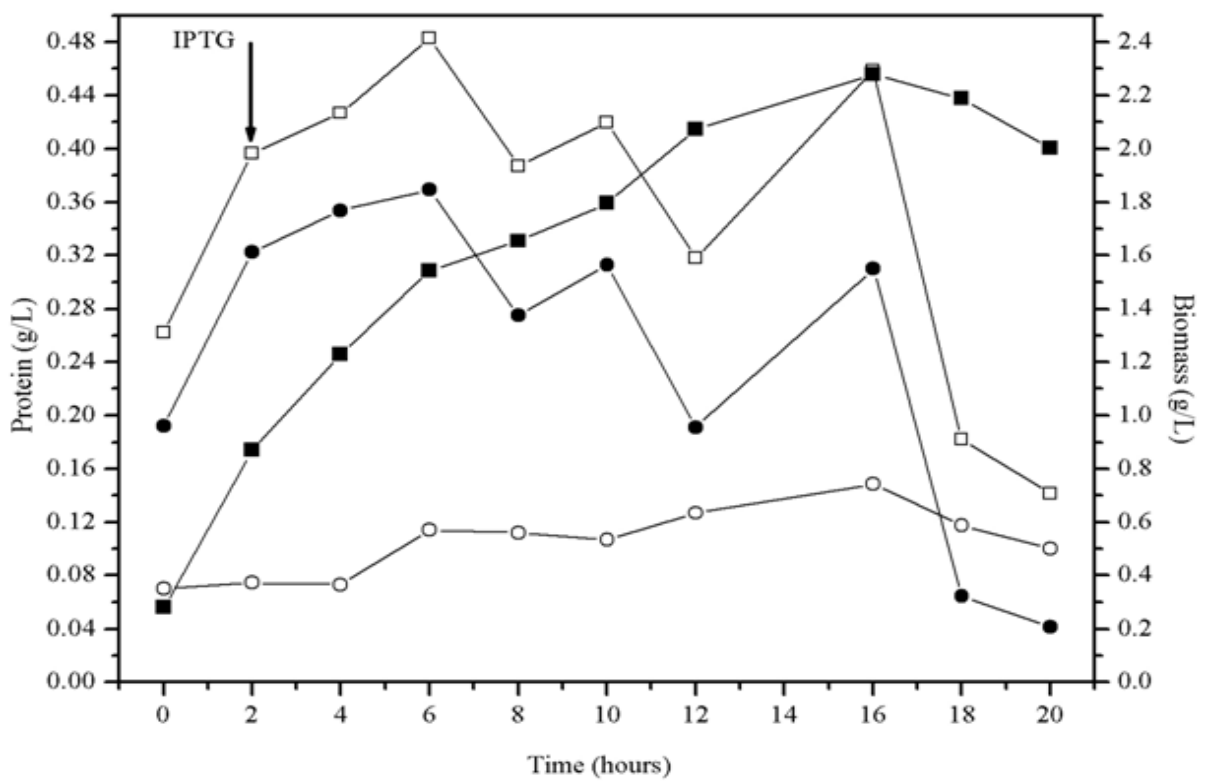

Figure 1. Curves of IPTG-induced eIF protein production in 2xTY: Intracellular $(\bullet)$, Extracellular $(\circ)$, Total Protein $(\square)$ and Biomass ( $\mathbf{\square})$.

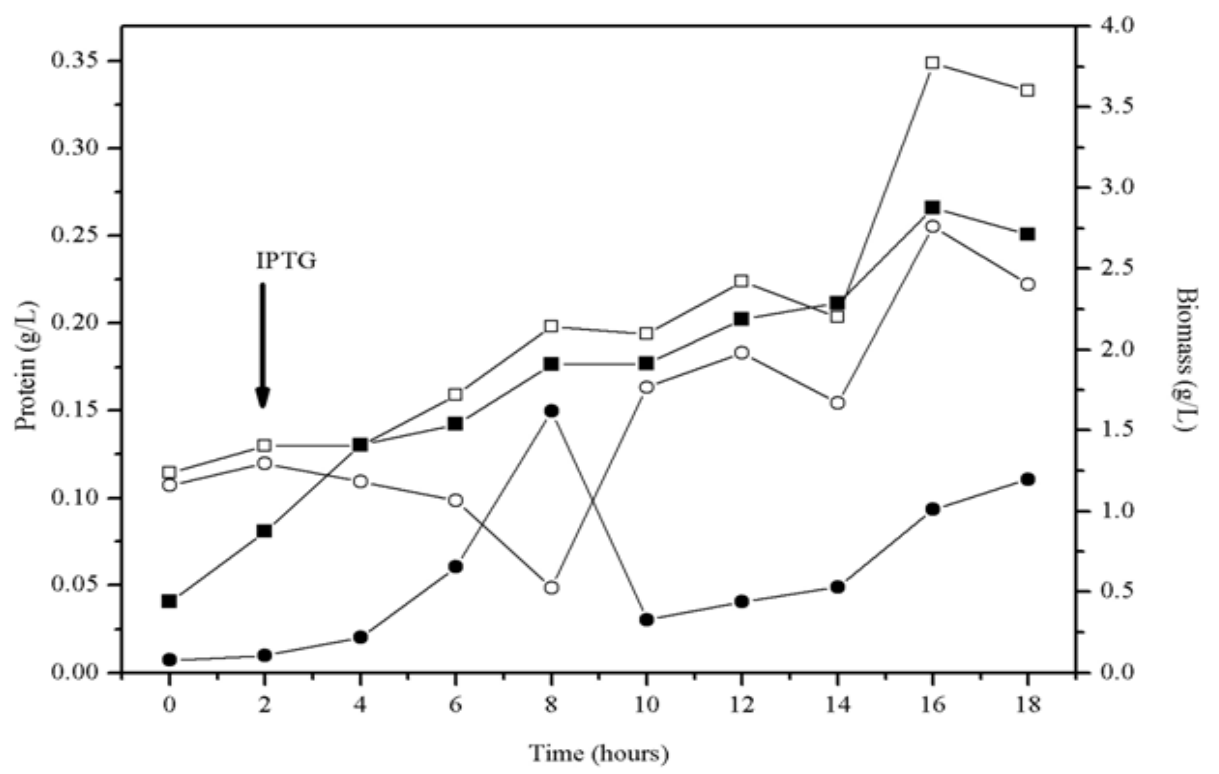

Figure 2. Curves of IPTG-induced eIF protein production in TB medium: Intracellular $(\bullet)$, Extracellular $(\circ)$, Total Protein $(\square)$ and Biomass ( $\mathbf{\square})$. 


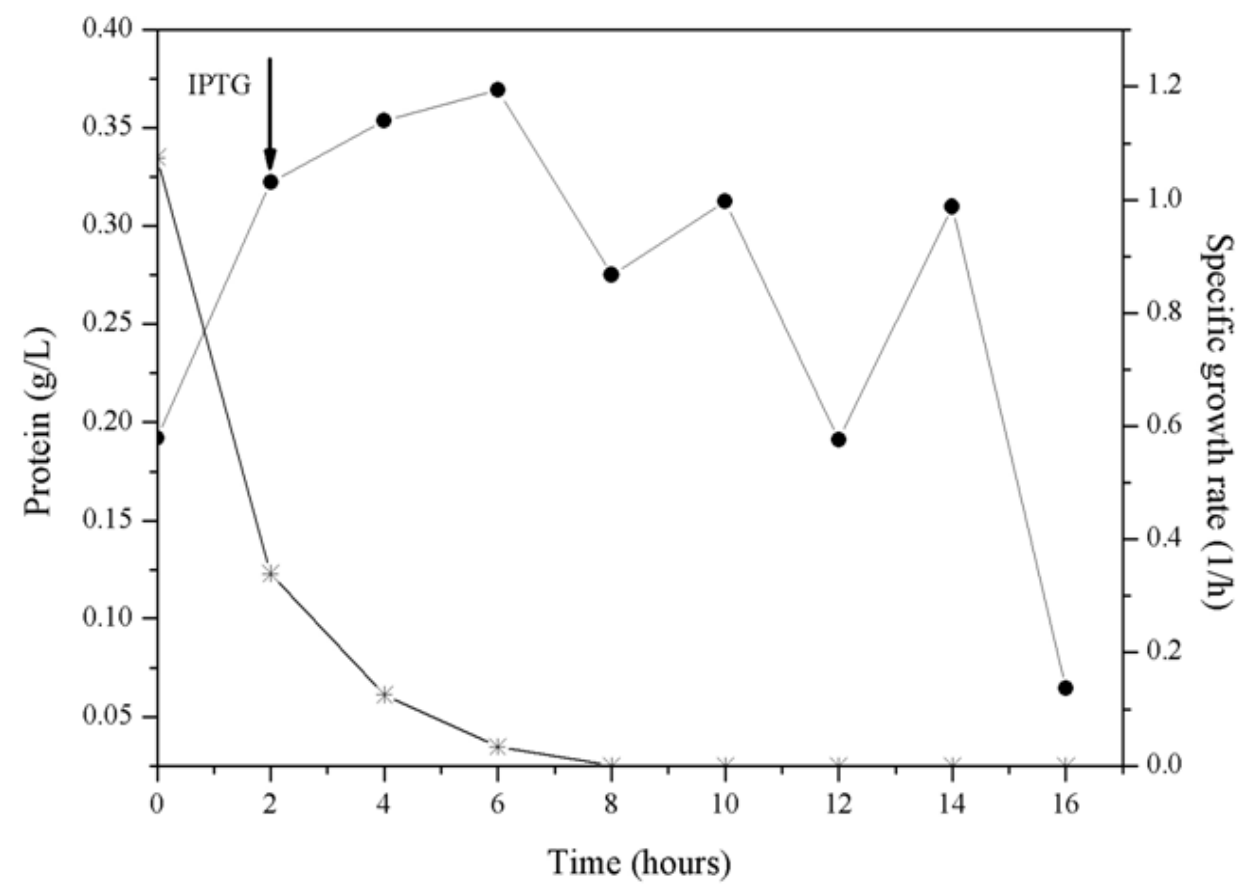

Figure 3. Curves of IPTG-induced intracellular production of the eIF recombinant protein $(\bullet)$ and specific growth rate $(*)$ in 2xTY medium.

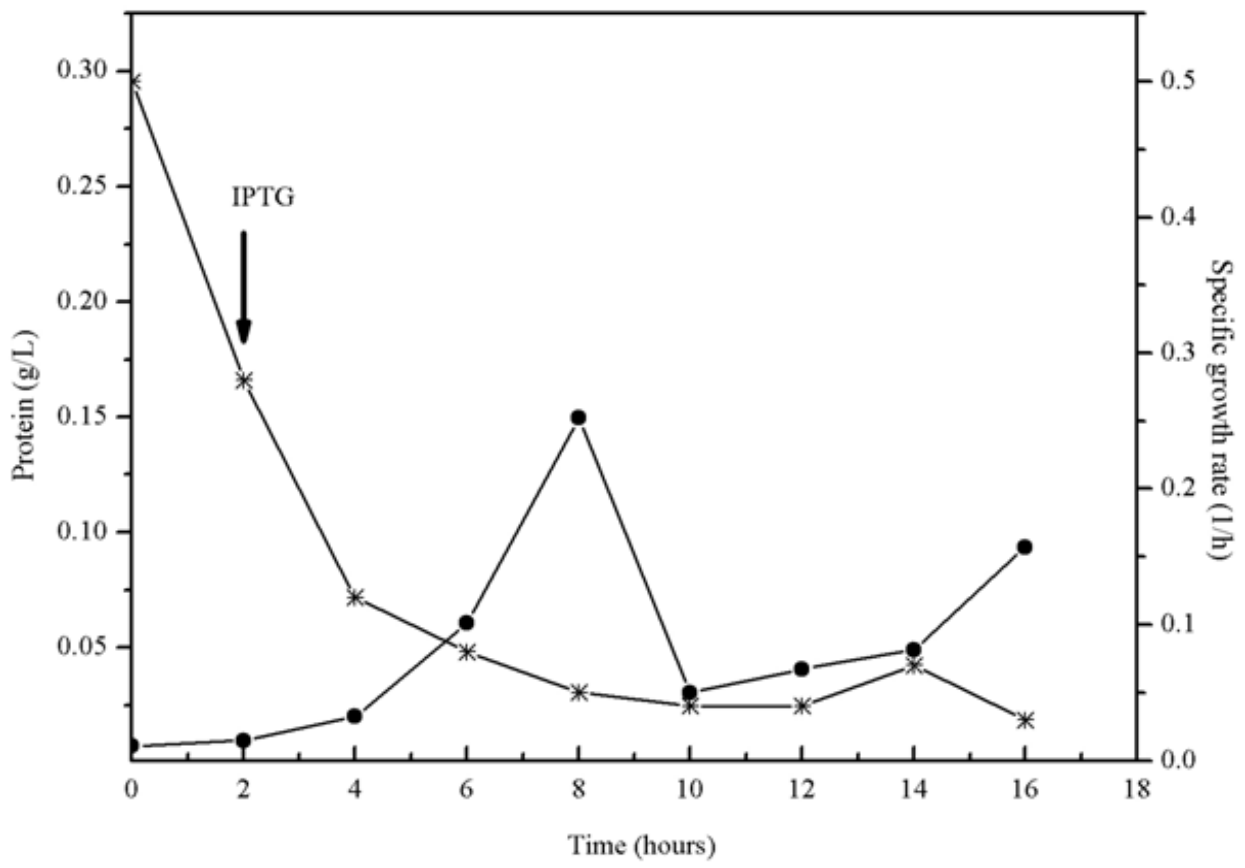

Figure 4. Curves of IPTG-induced intracellular production of the eIF recombinant protein $(\bullet)$ and specific growth rate (*) in TB medium. 
Figure 5A shows the eIF antigen as a protein band during protein of interest and a number of components present in the the second elution (line 4-8) with a molecular mass of medium. Moreover, it can be observed that fusion of the eIF approximately $62 \mathrm{kDa}$. In this case, extracellular protein protein to the histidine tail does not lead to post-translational concentration in 2xTY medium was $0.37 \mathrm{~g} / \mathrm{L}$. Figure 5B depicts processing by E. coli (19).

the eIF antigen as a protein band with a molecular mass of In conclusion, it was found that eIF antigen production is approximately $72 \mathrm{kDa}$. In this case, extracellular protein associated to growth, with maximum expression 4 hours after concentration in TB medium was $0.15 \mathrm{~g} / \mathrm{L}$. The difference in culture induction in $2 \mathrm{xTY}$ medium. High protein accumulation molecular mass of the same protein in different cultivation media was also observed during the exponential growth phase. could be a result of different medium composition. The increase Recombinant protein production in E. coli in $2 x T Y$ medium was in eIF molecular weight in the TB medium may be due to the considerably higher than in TB medium due to the addition of presence of amino acids in particular histidine (19). According to amino acids and high tryptone concentration. This may reduce Kubar and Fragaki (8), the difference in molecular weight with product degradation by proteases induced during amino acid different cultivation media is due to the association between the limitation.

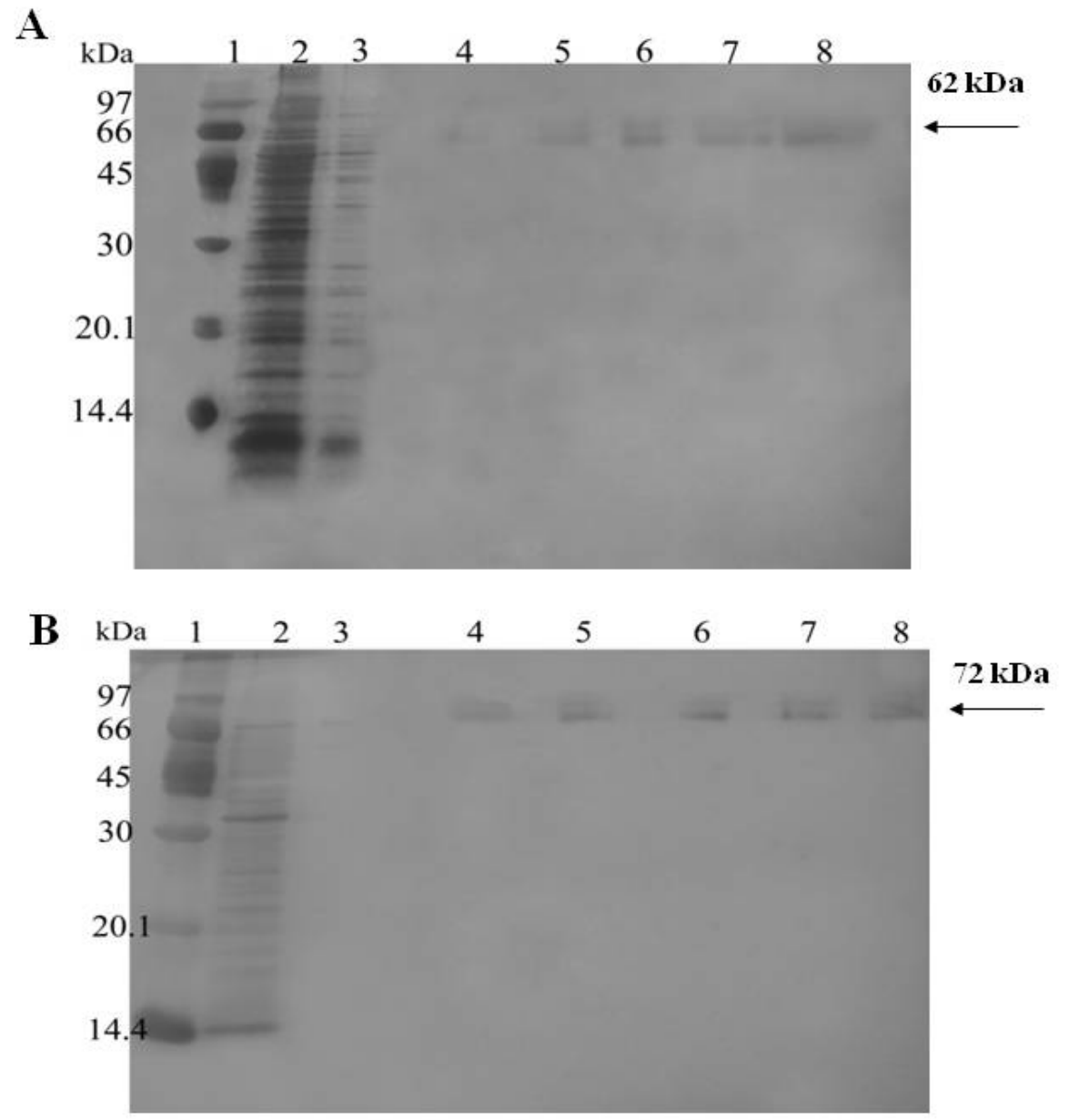

Figure 5. SDS-PAGE analysis of IPTG-induced eIF recombinant protein expression in 2xTY medium (A) and TB medium (B). Lane 1: protein molecular weight standards; Lane 2: total proteins; Lane 3: proteins not binding to the resin; Lane 4-8: eluted protein. 


\section{NOMENCLATURE}

IPTG

$\mathrm{kDa}$

$\mathrm{X}_{\max }$

$\mu_{\mathrm{xmax}}$

$\mathrm{Y}_{\mathrm{p} / \mathrm{x}}$

Isopropyl- $\beta-\mathrm{D}$ thiogalactopyranoside quilo daltons (1000 daltons)

Maximum cell concentration (g. $\left.\mathrm{L}^{-1}\right)$

Maximum specific growth rate $\left(\mathrm{h}^{-1}\right)$

Specific cell protein yield $(\mathrm{g} / \mathrm{g})$

\section{ACKNOWLEDGEMENTS}

The authors thank CNPq (Conselho Nacional de Pesquisa e Desenvolvimento Tecnológico) for the financial support and Dr. Mary Wilson (University of Lowa, U.S.A) for providing the microorganism strain.

\section{REFERENCES}

1. Arya, R.; Bhattacharya, A.; Saini, K.S. (2008). Dictyostelium discoideum- a promising expression system for the production of eukaryotic proteins. FASEB J. 22(12), 4055-4066.

2. Choi, J.H.; Keum, K.C.; Lee, S.Y. (2006). Production of recombinant proteins by high cell density culture of Escherichia coli. Chem. Eng. Sci. 61(3), 876-885.

3. Chuang, V.T.; Kragh-Hansen, U.; Otagiri, M. (2002). Pharmaceutical strategies utilizing recombinant human serum albumin. Pharm. Res. 19(5), 569-577.

4. Demain, A.L.; Vaishnav, P. (2009). Production of recombinant proteins by microbes and higher organisms. Biotechnol. Adv. 27(3), 297-306.

5. Ettinger, N.A.; Duggal, P.; Braz, R.F.; Nascimento, E.T.; Beaty, T.H.; Jeronimo, S.M.; Pearson, R.D.; Blackwell, J.M.; Moreno, L.; Wilson, M.E. (2009). Genetic admixture in Brazilians exposed to infection with Leishmania chagasi. Ann. Hum. Genet. 73(3), 304-313.

6. Hoffmann, F.; Van Den Heuvel, J.; Zidek, N.; Rinas, U. (2004). Minimizing inclusion body formation during recombinant protein production in Escherichia coli at bench and pilot plant scale. Enzyme Microb.Technol. 34, 235-241.

7. Jordan, E.; Michael, H.; Roth, A.; Biedendieck, R.; Schirrmann, T.; Jahn, D.; Dübel, S. (2007). Production of recombinant antibody fragments in Bacillus megaterium. Microb. Cell. Fact. 6(1), 1-11.

8. Kubar, J.; Fragaki, K. (2006). Leishmania proteins derived from recombinant DNA: current status and next steps. Trends Parasitol. 22(3), 111-116.

9. Laemmli, U.K. (1970). Cleavage of structural proteins during the assembly of the head of bacteriophage T4. Nature. 227(5259), 680-685.

10. Lowry, O.H.; Rosebrough, N.J.; Farr, A.L.; Randall, R.J. (1951). Protein measurement with the Folin-Phenol reagents. J. Biol. Chem. 193(1), 265-275.

11. Martins, D.R.; Jerômino, S.M.; Donelson, J.E.; Wilson, M.E. (2006). Leishmania chagasi $\mathrm{T}$-cell antigens identified through a double library screen. Infect. Immun. 74(12), 6940-6948.

12. Matsui, T.; Sato, H.; Yamamuro, H.; Misawa, S.; Shinzato, N.; Matsuda, H.; Takahashi, J.; Sato, S. (2008). High cell density cultivation of recombinant Escherichia coli for hirudin variant 1 production. J. Biotechnol. 134(1-2), 88-92.

13. Mayrink, W.; Botelho, A.C.; Magalhães, P.A.; Batista, S.M.; Lima, A.O.; Genaro, O.; Costa, C.A.; Melo, M.N.; Michalick, M.S.; Williams, P.; Dias, M.; Caiaffa, W.T.; Nascimento, E.; MachadoCoelho, G.L. (2006). Immunotherapy, immunochemotherapy and chemotherapy for American cutaneous leishmaniasis treatment. Rev. Soc. Bras. Med. Trop. 39(1), 14-21.

14. Nabel, G.J. (2004). Genetic, cellular and immune approaches to disease therapy: past and future. Nat. Med. 10(2), 135-141.

15. Panda, A.K.; Khan, R.H.; Appa Rao K.B.C. (1999). Kinetics of inclusion body production in batch and high cell density fed-batch culture of Escherichia coli expressing ovine growth hormone. $J$. Biotechnol. 75(2-3), 161-172.

16. Pei, X.; Wang, Q.; Qiu, X.; Ying, L.; Tao, J.; Xie, T. (2010). The fedbatch production of a thermophilic 2-deoxyribose-5-phosphate aldolase (DERA) in Escherichia coli by exponential feeding strategy control. Appl. Biochem Biotechnol. 162(5), 1423-1434.

17. Qiao, C.L.; Shen, B.C.; Xing, J.M.; Huang, B.J.; Zhang, J.L.; Zhao, D.X.; Yang, B. (2006). Culture and characteristics of recombinant protein production of an Escherichia coli strain expressing carboxylesterase B1. Int. Biodet. Biodeg. 58(2), 77-81.

18. Riesenberg, D.; Guthke, R. (1999). High-cell-density cultivation of microorganisms. Appl. Microbiol. Biotechnol. 51(4), 422-430.

19. Skeiky, Y.A.W.; Kennedy, M.; Kaufman, D.; Borges, M.M.; Guderian, J.A.; Scholler, J.K.; Ovendale, P.J.; Picha, K.S.; Morrissey, P.J.; Grabstein, K.H.; Campos-Neto, A.; Reed, S.G. (1998). LeIF: a recombinant Leishmania protein that induces an IL-12-mediated Th1 Cytokine profile. J. Immunol.161(11), 6171-6179.

20. Vidal, L.; Ferrer, P.; Alvaro, G.; Dolors Benaiges, M.; Caminal, G. (2005). Influence of induction and operation mode on recombinant rhamnulose 1-phosphate aldolase production by Eschericia coli using the T5 promoter. J. Biotechnol. 118(1), 75-87. 